DOE/ID-22238

Prepared in cooperation with the U.S. Department of Energy

Purgeable Organic Compounds at or near the Idaho Nuclear Technology and Engineering Center, Idaho National Laboratory, Idaho, 2015

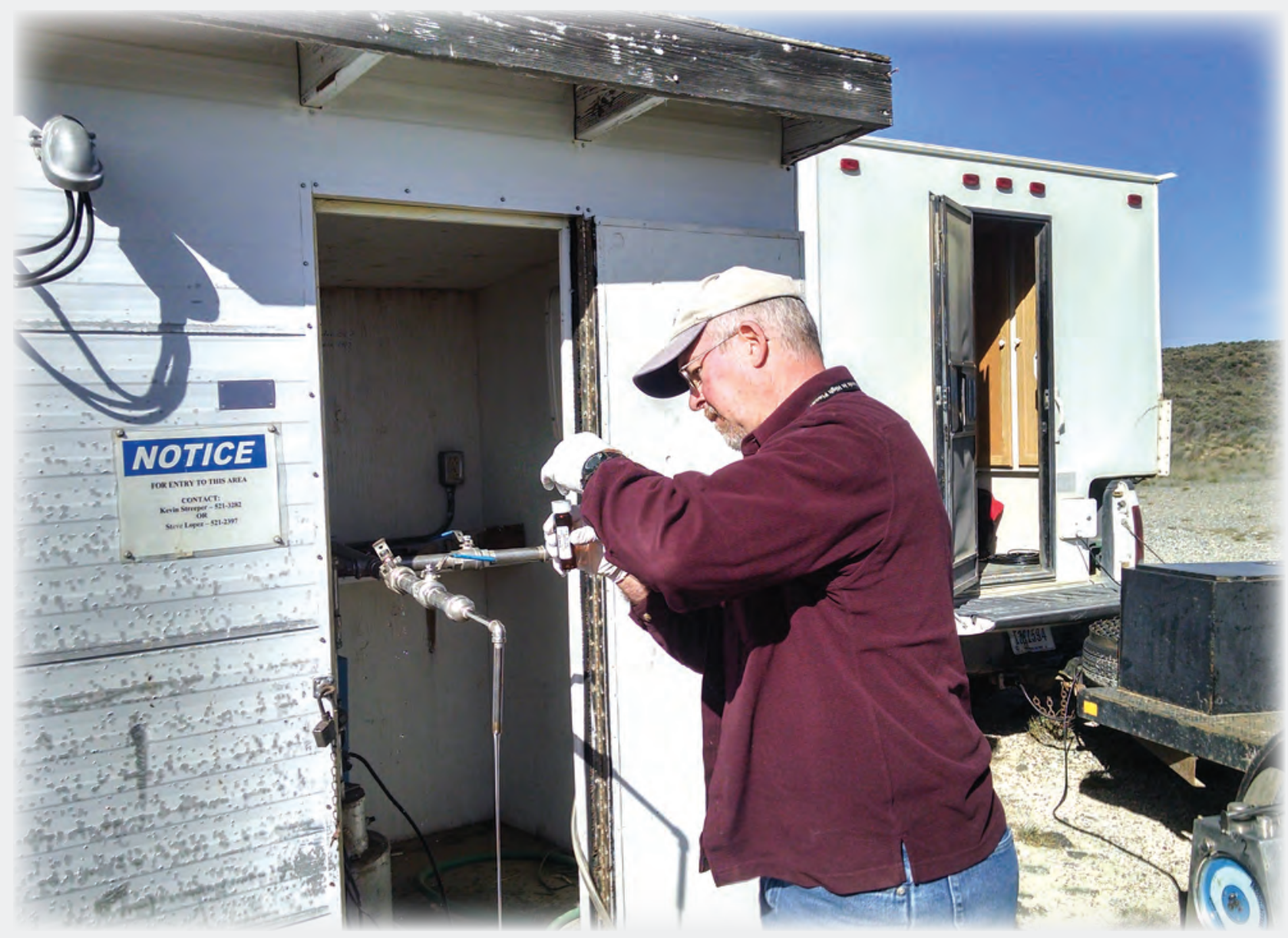

Open-File Report 2016-1083 
Cover: U.S. Geological Survey hydrologist collecting a purgeable organic compound sample at a well. (Photograph by Roy Bartholomay, USGS Idaho National Laboratory Project Office, April 13, 2015.) 


\section{Purgeable Organic Compounds at or near the Idaho Nuclear Technology and Engineering Center, Idaho National Laboratory, Idaho, 2015}

By Neil V. Maimer and Roy C. Bartholomay

DOE/ID-22238

Prepared in cooperation with the U.S. Department of Energy

Open-File Report 2016-1083

U.S. Department of the Interior

U.S. Geological Survey 


\section{U.S. Department of the Interior \\ SALLY JEWELL, Secretary}

\section{U.S. Geological Survey \\ Suzette M. Kimball, Director}

U.S. Geological Survey, Reston, Virginia: 2016

For more information on the USGS—-the Federal source for science about the Earth,

its natural and living resources, natural hazards, and the environment-visit

http://www.usgs.gov/ or call 1-888-ASK-USGS (1-888-275-8747).

For an overview of USGS information products, including maps, imagery, and publications, visit http://www.store.usgs.gov/.

Any use of trade, firm, or product names is for descriptive purposes only and does not imply endorsement by the U.S. Government.

Although this information product, for the most part, is in the public domain, it also may contain copyrighted materials as noted in the text. Permission to reproduce copyrighted items must be secured from the copyright owner.

Suggested citation:

Maimer, N.V., and Bartholomay, R.C., 2016, Purgeable organic compounds at or near the Idaho Nuclear Technology and Engineering Center, Idaho National Laboratory, Idaho, 2015: U.S. Geological Survey Open-File Report 2016-1083 (DOE/ID 22238), 17 p., http://dx.doi.org/10.3133/ofr20161083.

ISSN 2331-1258 (online) 


\section{Contents}

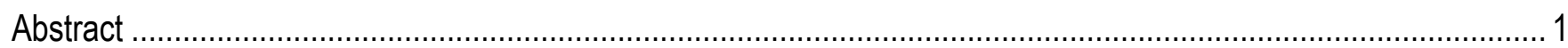

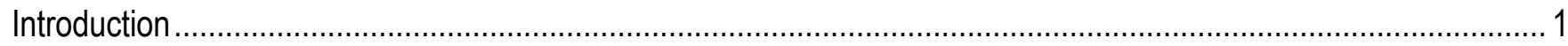

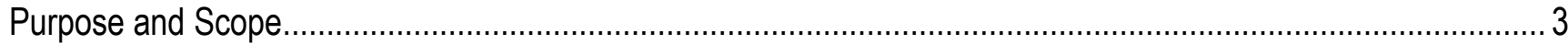

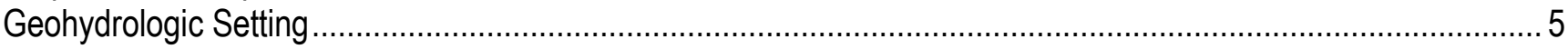

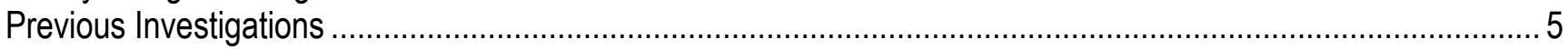

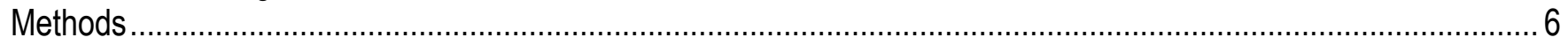

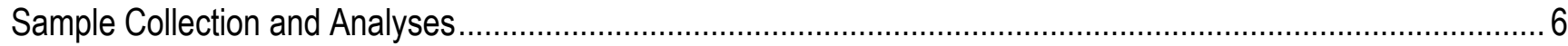

Quality Assurance/Quality Control ...............................................................................................

Guidelines for Interpreting Results of Chemical Analysis .......................................................................... 7

Purgeable Organic Compounds in Groundwater ………...........................................................................

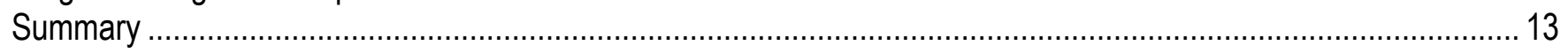

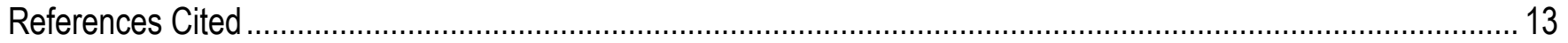

\section{Figures}

Figure 1. Map showing location of the Idaho National Laboratory and selected facilities, Idaho. 2

Figure 2. Map showing location of wells sampled for purgeable organic compounds at and near the Idaho Nuclear Technology and Engineering Center, Idaho National Laboratory, Idaho, 2015 4

\section{Tables}

Table 1. Reporting limits and maximum contaminant levels for purgeable organic compounds in groundwater at or near the Idaho Nuclear Technology and Engineering Center, Idaho National Laboratory, Idaho, 2015. 8 Table 2. Concentrations of selected purgeable organic compounds in groundwater at or near the Idaho Nuclear Technology and Engineering Center, Idaho National Laboratory, Idaho, 2015. 


\section{Conversion Factors}

Inch/Pound to International System of Units

\begin{tabular}{|c|c|c|}
\hline Multiply & By & To obtain \\
\hline \multicolumn{3}{|c|}{ Length } \\
\hline foot $(\mathrm{ft})$ & 0.3048 & meter $(\mathrm{m})$ \\
\hline mile (mi) & 1.609 & kilometer $(\mathrm{km})$ \\
\hline \multicolumn{3}{|c|}{ Area } \\
\hline square mile $\left(\mathrm{mi}^{2}\right)$ & 2.590 & square kilometer $\left(\mathrm{km}^{2}\right)$ \\
\hline \multicolumn{3}{|c|}{ Hydraulic conductivity } \\
\hline foot per day (ft/d) & 0.3048 & meter per day $(\mathrm{m} / \mathrm{d})$ \\
\hline \multicolumn{3}{|c|}{ Hydraulic gradient } \\
\hline foot per mile $(\mathrm{ft} / \mathrm{mi})$ & 0.1894 & meter per kilometer $(\mathrm{m} / \mathrm{km})$ \\
\hline \multicolumn{3}{|c|}{ Transmissivity* } \\
\hline foot squared per day $\left(\mathrm{ft}^{2} / \mathrm{d}\right)$ & 0.09290 & meter squared per day $\left(\mathrm{m}^{2} / \mathrm{d}\right)$ \\
\hline
\end{tabular}

${ }^{*}$ Transmissivity: The standard unit for transmissivity is cubic foot per day per square foot times foot of aquifer thickness [(ft $\left.\left.3 / \mathrm{d}\right) / \mathrm{ft}\right] \mathrm{ft}$. In this report, the mathematically reduced form, foot squared per day $\left(\mathrm{ft}^{2} / \mathrm{d}\right)$, is used for convenience.

Concentrations of chemical constituents in water are given in micrograms per liter $(\mu \mathrm{g} / \mathrm{L})$.

\section{Datum}

Horizontal coordinate information is referenced to the North American Datum of 1927 (NAD 27). 


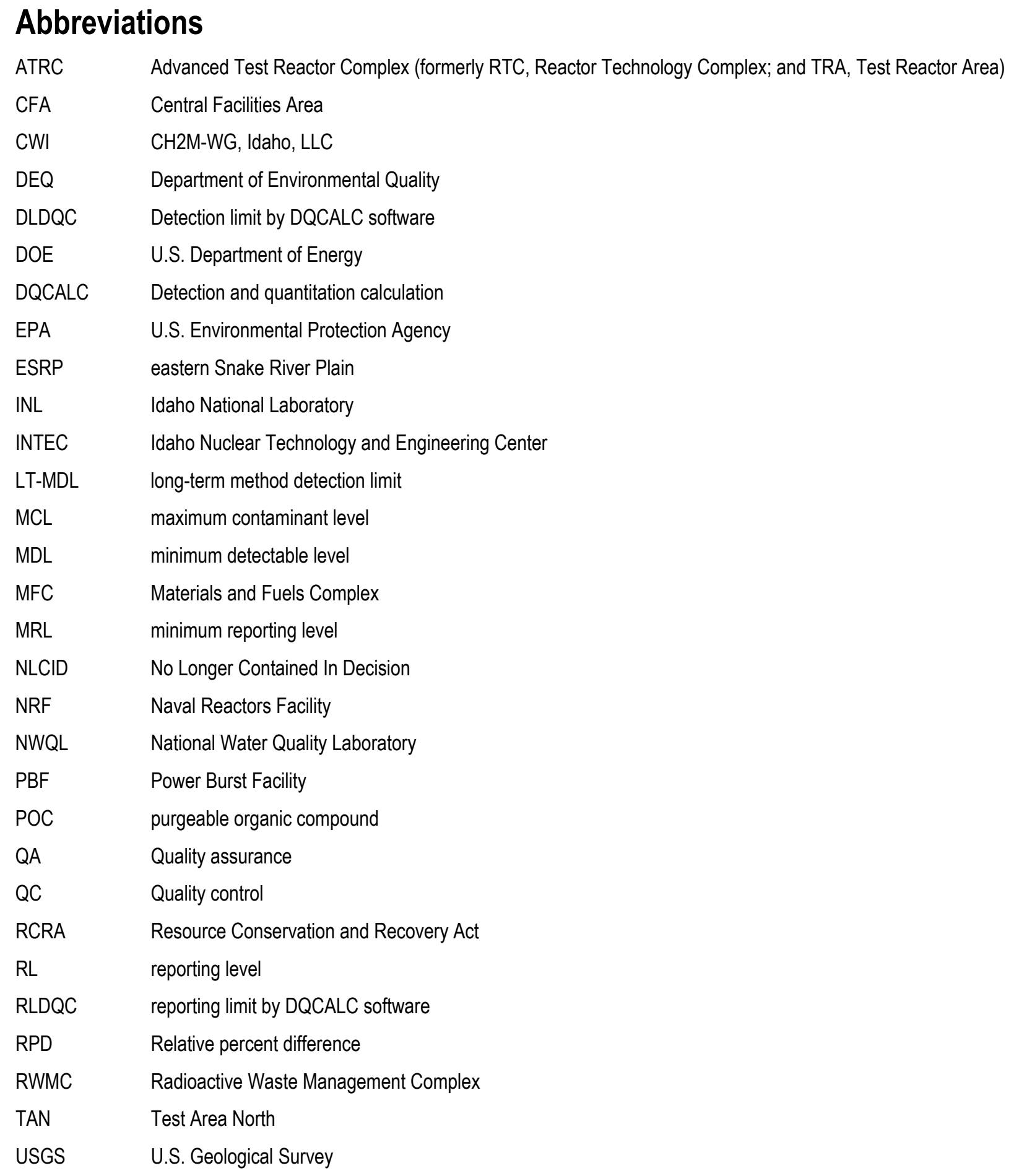


This page left intentionally blank 


\title{
Purgeable Organic Compounds at or near the Idaho Nuclear Technology and Engineering Center, Idaho National Laboratory, Idaho, 2015
}

\author{
By Neil V. Maimer and Roy C. Bartholomay
}

\begin{abstract}
During 2015, the U.S. Geological Survey, in cooperation with the U.S. Department of Energy, collected groundwater samples from 31 wells at or near the Idaho Nuclear Technology and Engineering Center (INTEC) at the Idaho National Laboratory for purgeable organic compounds (POCs). The samples were collected and analyzed for the purpose of evaluating whether purge water from wells located inside an areal polygon established downgradient of the INTEC must be treated as a Resource Conservation and Recovery Act listed waste.

POC concentrations in water samples from 29 of 31 wells completed in the eastern Snake River Plain aquifer were greater than their detection limit, determined from detection and quantitation calculation software, for at least one to four POCs. Of the 29 wells with concentrations greater than their detection limits, only 20 had concentrations greater than the laboratory reporting limit as calculated with detection and quantitation calculation software. None of the concentrations exceeded any maximum contaminant levels established for public drinking water supplies. Most commonly detected compounds were 1,1,1-trichoroethane, 1,1-dichloroethene, and trichloroethene.
\end{abstract}

\section{Introduction}

The Idaho National Laboratory (INL), operated by the U.S. Department of Energy (DOE), encompasses about $890 \mathrm{mi}^{2}$ of the eastern Snake River Plain (ESRP) in southeastern Idaho (fig. 1). The INL was established in 1949 to develop atomic energy, nuclear safety, defense programs, environmental research, and advanced energy concepts. Wastewater disposal sites at the Test Area North (TAN), the Naval Reactors Facility (NRF), the Advanced Test Reactor Complex (ATR Complex), and the Idaho Nuclear Technology and Engineering Center (INTEC) (fig. 1) have contributed radioactive- and chemical-waste contaminants to the ESRP aquifer. These sites incorporated various wastewater disposal methods, including lined evaporation ponds, unlined percolation (infiltration) ponds and ditches, drain fields, and injection wells. Waste materials buried in shallow pits and trenches within the Subsurface Disposal Area at the Radioactive Waste Management Complex (RWMC) also have contributed contaminants to groundwater. 

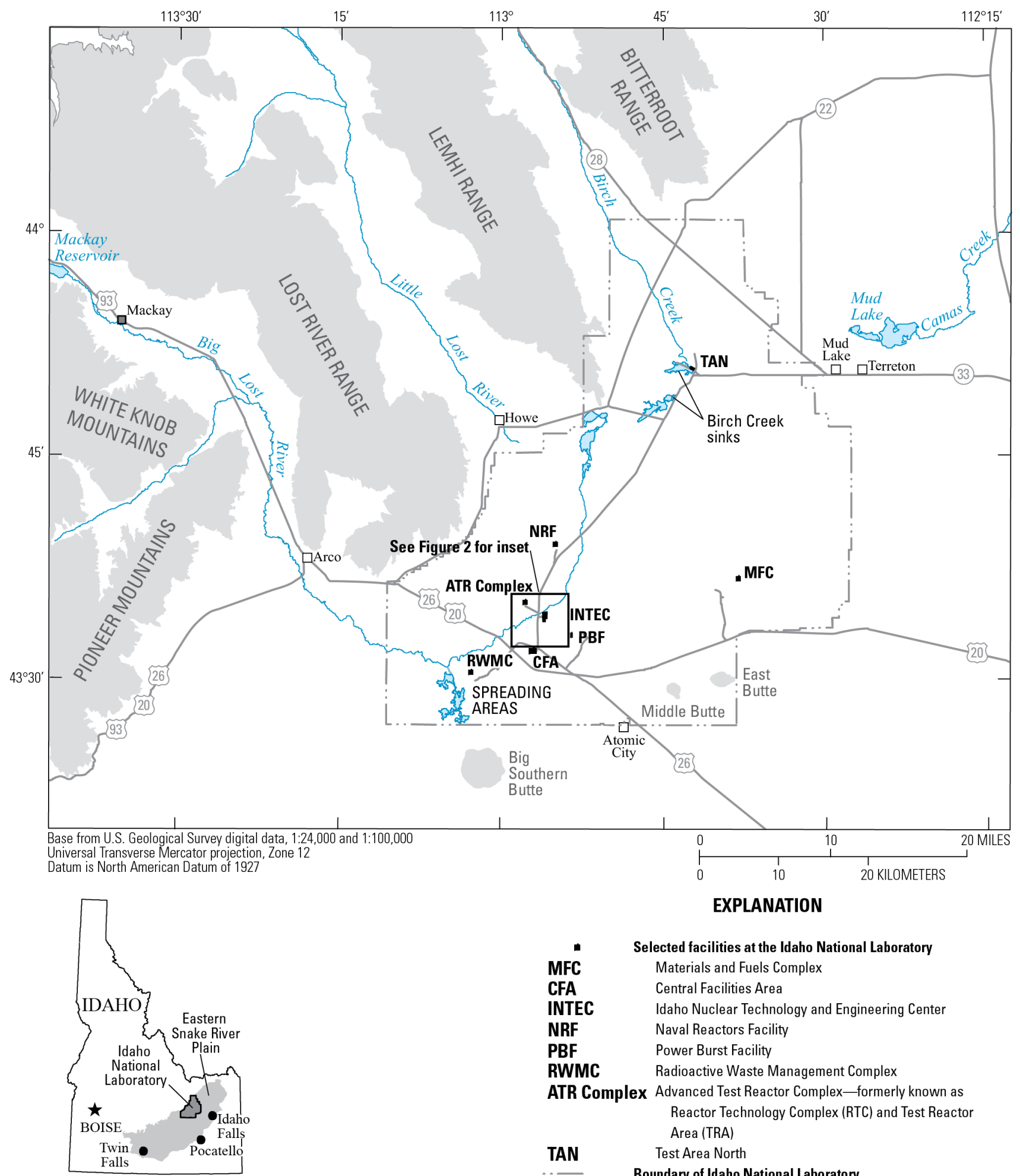

\begin{tabular}{lc} 
MFC & Selected facilities at the Idaho National Laboratory \\
CFA & Materials and Fuels Complex \\
INTEC & Central Facilities Area \\
NRF & Idaho Nuclear Technology and Engineering Center \\
PBF & Naval Reactors Facility \\
RWMC & Power Burst Facility \\
ATR Complex & Radioactive Waste Management Complex \\
& Reactor Technology Complex (RTC) and Test Reactor \\
& Area (TRA) \\
TAN & Test Area North \\
\hline & Boundary of Idaho National Laboratory
\end{tabular}

Figure 1. Map showing location of the Idaho National Laboratory and selected facilities, Idaho. 
Since 1949, the U.S. Geological Survey (USGS) has worked in cooperation with the DOE at the INL to define: (1) the quality and availability of water for human consumption, (2) the usability of the water for supporting construction and cooling of facilities, (3) the location and movement of contaminants in the ESRP aquifer and perched groundwater zones, (4) the sources of recharge to the aquifer, (5) an early detection network for contaminants moving past the INL boundaries, and (6) the processes controlling the origin and distribution of contaminants and naturally occurring constituents in the aquifer (Ackerman and others, 2010).

In 2000, an areal polygon was established downgradient of the INTEC with groundwater that contained Resource Conservation and Recovery Act (RCRA) listed waste from the INTEC disposal well (fig. 2). In August 2000, the Idaho Department of Environmental Quality (DEQ) granted a conditional No Longer Contained In Decision (NLCID) to DOE, which allowed for groundwater removed from specific wells in the polygon to be discharged to the ground surface (Brian Monson, Idaho Department of Environmental Quality, written commun., August 21, 2000). The conditional NLCID was renewed by the DEQ in June 2002 (Brian Monson, Idaho Department of Environmental Quality, written commun., June 19, 2002), but was withdrawn in June 2003 (Brian Monson, Idaho Department of Environmental Quality, written commun., May 19, 2003). Beginning in October 2003, the USGS was no longer allowed to discharge purge water to the ground surface. DEQ required that purge water inside the areal polygon (fig. 2) be treated as RCRA-listed waste, which necessitated pumping it into containers and transporting it to an approved disposal site.

In 2015, INL contractor CH2M-WG, Idaho, LLC (CWI) in discussions with DOE, DEQ, and the U.S. Environmental Protection Agency (EPA) decided it was time to revisit the management decision made to include all the wells in the areal polygon in the RCRA "Contained In" listed hazardous waste. CWI evaluated the management approach, discussed it with DOE, EPA, and DEQ, and the agencies determined that if sufficient data became available, the size of the polygon (and number of wells containerized) could be reduced if analytical data showed that INTEC listed waste constituents are not present at concentrations greater than the minimum detectable levels (MDL) in the groundwater from those wells (Scott Reno, CH2M-WG, Idaho, LLC, written commun., February 10, 2015). It was determined that recent data were needed for carbon tetrachloride, tetrachloroethylene, trichloroethene, 1,1,1-trichloroethane, benzene, carbon disulfide, and toluene.

\section{Purpose and Scope}

The purpose of this report is to present results of purgeable organic compound (POC) sampling from wells the USGS sample at and near INTEC to determine whether concentrations of benzene, carbon disulfide, carbon tetrachloride, 1,1,1-trichloroethane, tetrachloroethylene, toluene, and trichloroethene, are equal to or greater than current MDLs. Samples were collected from 31 wells in 2015 to determine POCs. A sample schedule was used that included the seven compounds needed for a NLCID determination along with 42 other POCs. Samples were analyzed at the USGS National Water Quality Laboratory (NWQL) in Lakewood, Colorado. Results will be used to determine if future containerization of wells in the USGS sample program is needed. 


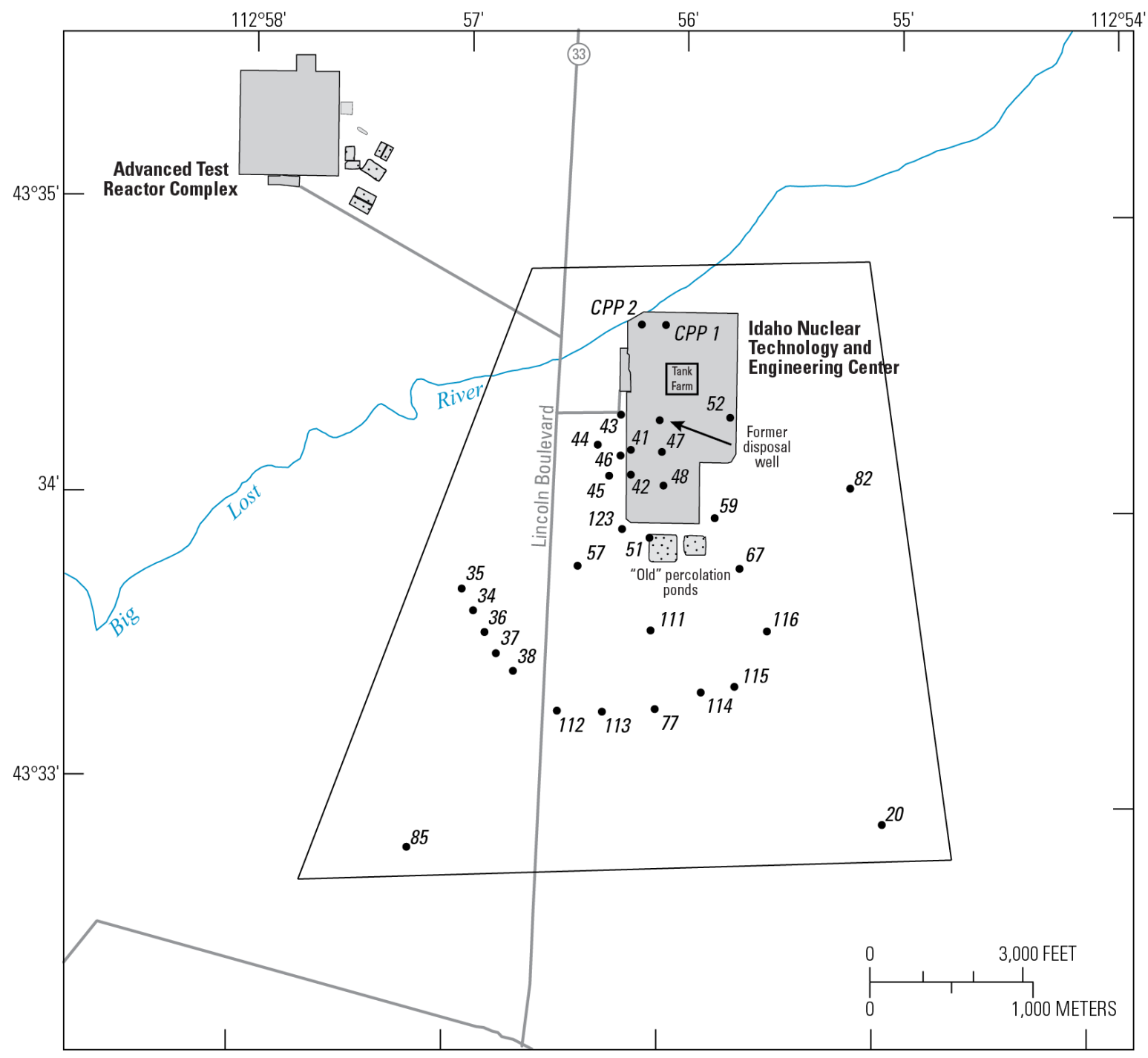

Base from U.S. Geological Survey digital data, 1:24,000 and 1:100,000 Universal Transverse Mercator projection, Zone 12

Datum is North American Datum of 1927

$\left.\right|_{0} ^{0}+\left.\left.\right|_{1,1} ^{3,000 \text { FEET }}\right|_{1,000 \text { METERS }} ^{1}$

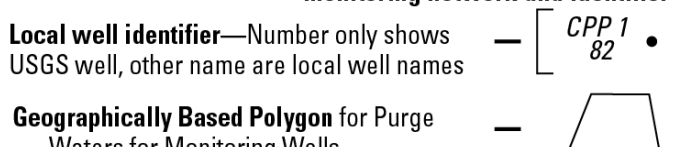

Well in the USGS aquifer water-quality monitoring network and identifier Waters for Monitoring Wells

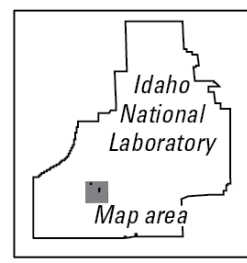

Figure 2. Map showing location of wells sampled for purgeable organic compounds at and near the Idaho Nuclear Technology and Engineering Center, Idaho National Laboratory, Idaho, 2015. 


\section{Geohydrologic Setting}

The INL is located on the west-central part of the ESRP. The ESRP is a northeast-trending structural basin about $200 \mathrm{mi}$ long and 50-70 mi wide. The basin has been filled with basaltic lava flows interbedded with terrestrial sediments. The basaltic rocks and sedimentary deposits combine to form the ESRP aquifer, which is the primary source of groundwater for the ESRP.

The ESRP aquifer is one of the most productive aquifers in the United States (U.S. Geological Survey, 1985, p. 193). Groundwater generally moves from northeast to southwest and discharges to springs along the Snake River downstream of Twin Falls, Idaho, about $100 \mathrm{mi}$ southwest of the INL (fig. 1). Groundwater moves horizontally through basalt interflow zones and vertically through joints and inter-fingering edges of basalt flows. Infiltration of surface water, pumpage from groundwater wells, geohydrologic conditions, and seasonal fluxes of recharge and discharge locally affect the movement of groundwater (Garabedian, 1986). The ESRP aquifer is recharged primarily from infiltration of applied irrigation water, infiltration of streamflow, groundwater inflow from adjoining mountain drainage basins, and infiltration of precipitation (Ackerman and others, 2006).

At the INL, depth to water in wells completed in the ESRP aquifer ranges from about $200 \mathrm{ft}$ below land surface in the northern part of the INL to more than $900 \mathrm{ft}$ below land surface in the southeastern part of the INL. Depth to water near INTEC is about $475 \mathrm{ft}$ below land surface. A significant proportion of the groundwater moves through the upper 200-800 $\mathrm{ft}$ of basaltic rock (Mann, 1986, p. 21). Ackerman (1991, p. 30) and Bartholomay and others (1997, table 3) reported transmissivity values for basalt in the upper part of the aquifer ranging from 1.1 to $760,000 \mathrm{ft}^{2} / \mathrm{d}$. The hydraulic gradient at the INL ranges from 2 to $10 \mathrm{ft} / \mathrm{mi}$, with an average of $4 \mathrm{ft} / \mathrm{mi}$ (Davis and others, 2013, fig. 9). Horizontal flow velocities of 2-26 ft/d have been calculated based on the movement of various constituents in different areas of the aquifer at and near the INL (Robertson and others, 1974; Mann and Beasley, 1994; Cecil and others, 2000; Plummer and others, 2000; and Busenberg and others, 2001). These flow rates equate to a travel time of about 50-700 years for water beneath the INL to travel to springs that discharge at the terminus of the ESRP groundwater-flow system near Twin Falls, Idaho. Localized tracer tests at the INL have shown that vertical- and horizontal-transport rates are as high as 60-150 ft/d (Nimmo and others, 2002; Duke and others, 2007).

\section{Previous Investigations}

Hydrologic conditions and the distribution of selected wastewater constituents in groundwater are discussed in a series of reports describing the INL. A list of all reports published by the USGS on project work done at the INL is available at http://id.water.usgs.gov/INL/Pubs/.

Previous investigations of the POCs in groundwater at the INL have been done by Leenheer and Bagby (1982), Mann and Knobel (1987), Mann (1990), Liszewski and Mann (1992), and Greene and Tucker (1998). Hydrologic conditions reports that discuss POCs in the ESRP aquifer at the INL include Bartholomay and others (1995, 1997, and 2000); Davis (2006, 2008, and 2010); and Davis and others (2013). Davis and others (2015) described water quality trends for POCs at and near INTEC and RWMC and found wells near INTEC had decreasing trends for 1,1,1-trichloroethane and 1,1dichloroethene. 


\section{Methods}

\section{Sample Collection and Analyses}

Water samples were collected according to procedures described in the USGS National Field manual (U.S. Geological Survey, variously dated) and the USGS INL Project Office quality assurance plan (Bartholomay and others, 2014). After collection, samples were chilled and sent to the NWQL for analyses. Methods used to analyze the samples followed guidelines outlined in Goerlitz and Brown (1972), Wershaw and others (1987), Fishman (1993), and Rose and Schroeder (1995).

Water samples were placed in containers and preserved in accordance with laboratory requirements specified by the NWQL. Containers and preservatives used for this study were supplied by the NWQL and were processed using a rigorous quality-control procedure to minimize sample contamination (Pritt, 1989, p. 75).

\section{Quality Assurance/Quality Control}

Beginning in 1980, about 10 percent of water samples were collected for quality assurance (QA) purposes. Quality control (QC) water samples collected by the USGS INL Project Office generally include equipment blanks, splits, and replicates; however, other types of QC samples also have been collected throughout the history of the program. Comparative studies to determine agreement between analytical results for water-sample pairs by laboratories used by the INL Project Office QA program were summarized by Wegner (1989), Williams (1996, 1997), Rattray (2012), Davis and others, (2013), and Rattray (2014).

For this study, three replicate pairs were collected. The NWQL does not provide uncertainty for POCs, therefore the relative percent difference (RPD) was selected to compare equivalency of replicate pairs. The RPD is calculated based on the formula:

$$
R P D=((A B S(X 1-X 2)) /((X 1+X 2) / 2)) * 100
$$

where

$R P D \quad$ is the relative percent difference,

$A B S \quad$ is the absolute value,

$X 1 \quad$ is the result for primary environmental sample, and

$X 2 \quad$ is the result for field-replicate sample.

A typical data-quality objective for field-replicate samples is a maximum RPD of 20 percent (Taylor, 1987). Sample pairs that had both concentrations less than the reporting limits were considered statistically equivalent. For the constituents (1,1,1-trichloroethane, trichloroethene, and 1,1dichloroethene) with concentrations greater than the detection limits, using equation 1, RPDs ranged from 0.2 to 16.4 percent for all eight sample pairs (100 percent) and can be considered statistically equivalent using this test. 


\section{Guidelines for Interpreting Results of Chemical Analysis}

Water samples were analyzed for POCs at the NWQL in Lakewood, Colorado. NWQL reporting levels (RL) for ambient POC analytical results are determined using detection and quantitation calculation (DQCALC) software and are presented as a reporting limit by DQCALC (RLDQC) and minimum reporting level (MRL). The MRL is the smallest measured constituent concentration that can be reliably reported using a specific analytical method (Timme, 1995). The RLDQC is one of four new reporting level codes adopted by the NWQL to replace the long-term method detection limit (LT-MDL) and is equal to (or greater than) two times the detection limit DQCALC (DLDQC) (U.S. Geological Survey, 2015, p. 11). DLDQC is described as the lowest concentration that with 90 percent confidence will be exceeded no more than 1 percent of the time when a blank sample is measured $(\leq 1$ percent false positive risk.) (U.S. Geological Survey, 2015, p. 11). DQCALC is a Microsoft ${ }^{\circledR}$ Excel-based software package used to compute a method detection estimate (Standard Practice D7510-10; American Society for Testing Materials International, 2010). A more detailed explanation of the DQCALC procedures is available in U.S. Geological Survey (2015). Childress and others (1999) provide details about the approach used by the USGS regarding detection limits and reporting limits.

\section{Purgeable Organic Compounds in Groundwater}

The 49 POCs for which analyses were performed along with their respective reporting limit (RLDQC) and EPA maximum contaminant level (MCL) for public drinking water supplies are shown in table 1. None of the POC concentrations greater than the RLDQC exceeded MCLs or proposed MCLs established by the EPA.

Concentrations in water samples from 29 of the 31 wells completed in the ESRP aquifer were greater than the DLDQC of at least one of the eight constituents in table 2. None of the concentrations exceeded any MCLs established for public drinking water supplies. Concentrations for all other constituents sampled were less than their RLDQC. Concentrations of 1,1,1-trichloroethane were greater than the DLDQC in 28 wells and ranged from 0.013 to $0.093 \mu \mathrm{g} / \mathrm{L}$. Concentrations of 1,1dichloroethene were greater than the DLDQC in 25 wells and ranged from 0.011 to $0.183 \mu \mathrm{g} / \mathrm{L}$. Concentrations of trichloroethene were greater than the DLDQC in six wells and ranged from 0.011 to $0.076 \mu \mathrm{g} / \mathrm{L}$. Concentrations of chloroform were detected in two wells and tetrachloroethylene in one well (table 2). Concentrations of 1,1,1-trichloroethane were greater than the RLDQC in 21 of 29 wells, and had an additional 8 wells with concentrations greater than the DLDQC but less than the RLDQC. The RLDQC is two times the DLDQC. There were two wells with a concentration greater than the RLDQC for trichloroethene and four wells greater than the DLDQC but less than the RLDQC. The two chloroform concentrations and one tetrachloroethylene concentration were less than the RLDQC. Onehalf the wells were sampled in April when seasonal water levels in the aquifer are highest and one-half the wells were sampled in October when seasonal water levels are at their lowest (Bartholomay and Twining, 2015). No temporal variability was evident. 
Table 1. Reporting limits and maximum contaminant levels for purgeable organic compounds in groundwater at or near the Idaho Nuclear Technology and Engineering Center, Idaho National Laboratory, Idaho, 2015.

[Analyses were performed by the U.S. Geological Survey's National Water Quality Laboratory using an analytical method that conforms to U.S. Environmental Protection Agency method 524 (Pritt and Jones, 1989). Reporting limit by detection and quantitation calculation (DQCALC) and maximum contamination levels are expressed in micrograms per liter $(\mu \mathrm{g} / \mathrm{L})$. RLDQC: Reporting limit by DQCALC. MCL: Maximum contaminant level. --, no data available]

\begin{tabular}{|c|c|c|c|c|c|}
\hline Compound & RLDQC & MCL & Compound & RLDQC & MCL \\
\hline 1,1,1,2-Tetrachloroethane & 0.040 & -- & Chloroform & 0.03 & $\left(\begin{array}{l}1 \\
)\end{array}\right.$ \\
\hline 1,1,1-Trichloroethane & 0.030 & 200 & Chloromethane & ${ }^{2} 0.1$ & -- \\
\hline 1,1,2-Trichloroethane & 0.046 & 5 & cis-1,2-Dichloroethylene & 0.022 & 70 \\
\hline 1,1-Dichloroethane & 0.022 & -- & cis-1,3-Dichloropropene & 0.1 & -- \\
\hline 1,1-Dichloroethene & 0.022 & 7 & Dibromochloromethane & 0.12 & $\left(\begin{array}{l}1 \\
)\end{array}\right.$ \\
\hline 1,1-Difluoroethane & 0.022 & -- & Dichlorofluoromethane & 0.05 & -- \\
\hline 1,2,3,4-Tetrahydronapthalene & 0.08 & -- & Dichloromethane & ${ }^{2} 0.04$ & 5 \\
\hline 1,2,4-Trichlorobenzene & 0.08 & 70 & Ethylbenzene & 0.036 & 700 \\
\hline 1,2,4-Trimethylbenzene & 0.032 & -- & Hexane & 0.024 & -- \\
\hline 1,2-Dichloro-1,1,2,2-tetrafluoroethane & 0.03 & -- & $n$-Pentane & 0.022 & -- \\
\hline 1,2-Dichlorobenzene & 0.028 & 600 & $n$-Propylbenzene & 0.036 & -- \\
\hline 1,2-Dichloroethane & 0.08 & 5 & Naphthalene & 0.26 & -- \\
\hline 1,3-Butadiene & 0.08 & -- & sec-Butylbenzene & 0.034 & -- \\
\hline 1,4-Dichlorobenzene & 0.026 & 75 & Styrene & 0.042 & 100 \\
\hline 1-Chloro-1,1-difluoroethane & 0.034 & -- & methyl tert-butyl ether & 0.1 & -- \\
\hline 2,2-Dichloro-1,1,1-trifluoroethane & 0.014 & & Tetrachloroethylene & 0.026 & 5 \\
\hline Benzene & 0.026 & 5 & Tetrachloromethane & 0.06 & 5 \\
\hline Bromochloromethane & 0.06 & -- & Toluene & ${ }^{2} 0.02$ & 1,000 \\
\hline Bromodichloromethane & 0.034 & $\left({ }^{1}\right)$ & trans-1,2-Dichloroethylene & 0.0018 & 100 \\
\hline Bromoform & 0.1 & $\left(\begin{array}{l}1 \\
()\end{array}\right.$ & trans-1,3-Dichloropropene & 0.24 & -- \\
\hline Bromomethane & 0.2 & -- & Trichloroethylene & 0.022 & 5 \\
\hline Butane & 0.038 & -- & Vinyl chloride & 0.06 & 2 \\
\hline Carbon disulfide & 0.1 & -- & $m$ - and $p$-Xylene & 0.08 & $\left({ }^{3}\right)$ \\
\hline Chlorobenzene & 0.026 & 100 & $o$-Xylene & 0.032 & $(3)$ \\
\hline Chlorodifluoromethane & 0.18 & -- & & & \\
\hline
\end{tabular}

${ }^{1}$ Sum of the concentrations of all four trihalomethanes-bromoform, chloroform, bromodichloromethane and dibromochloromethane_cannot exceed $80 \mu \mathrm{g} / \mathrm{L}$ as an annual average.

${ }^{2}$ Minimum reporting level (MRL).

${ }^{3}$ Sum of the concentrations of all three xylenes—ortho-xylene, meta-xylene and para-xylene — cannot exceed $10,000 \mu \mathrm{g} / \mathrm{L}$, http://water.epa.gov/drink/contaminants/basicinformation/disinfectionbyproducts.cfm. 
Table 2. Concentrations of selected purgeable organic compounds in groundwater at or near the Idaho Nuclear Technology and Engineering Center, Idaho National Laboratory, Idaho, 2015.

[Analyses were performed by the U.S. Geological Survey's National Water Quality Laboratory using an analytical method that conforms to U.S. Environmental Protection Agency method 524 (Pritt and Jones, 1989). Concentrations are given in micrograms per liter $(\mu \mathrm{g} / \mathrm{L}) .<0.02$ indicates the concentration was less than the reporting level of $0.02 \mu \mathrm{g} / \mathrm{L}$. Concentrations in bold indicate value exceeds the reporting level. Value Qualifier Codes: b, value extrapolated below the lowest calibration standard; c, see laboratory comments for this result (the reporting level was increased due to interference/the parameter 77041 (carbon disulfide) is a highly variable compound in schedule 4436); $\mathrm{m}$, highly variable compound using this method (flake); questionable precision, and/or accuracy; $\mathrm{n}$, less than the reporting level but equal to or greater than the detection level; $t$, less than the detection level. Replicate, a second sample submitted for analysis using a different identifier. Abbreviations: NA, not applicable. RPD, relative percent difference]

\begin{tabular}{|c|c|c|c|c|c|c|c|c|c|c|}
\hline $\begin{array}{l}\text { Station } \\
\text { name }\end{array}$ & Station ID & Date sampled & Benzene & RPD & $\begin{array}{l}\text { Carbon } \\
\text { disulfide }\end{array}$ & RPD & $\begin{array}{c}\text { Carbon } \\
\text { tetrachloride }\end{array}$ & RPD & $\begin{array}{c}1,1,1- \\
\text { Trichloroethane }\end{array}$ & RPD \\
\hline CPP 1 & 433433112560201 & $04 / 09 / 15$ & $<0.026$ & NA & $<0.1$ & NA & $<0.06$ & NA & $0.013 \mathrm{~b}, \mathrm{t}$ & NA \\
\hline CPP 2 & 433432112560801 & $10 / 08 / 15$ & $<0.026$ & NA & $<0.1 \mathrm{c}, \mathrm{m}$ & $\mathrm{NA}$ & $<0.06$ & NA & $<0.030$ & $\mathrm{NA}$ \\
\hline USGS 20 & 433253112545901 & $04 / 08 / 15$ & $<0.026$ & NA & $<0.1$ & NA & $<0.06$ & NA & 0.041 & NA \\
\hline USGS 34 & 433334112565501 & $04 / 21 / 15$ & $<0.026$ & NA & $<0.1$ & NA & $<0.06$ & NA & 0.050 & NA \\
\hline USGS 35 & 433339112565801 & $10 / 05 / 15$ & $<0.026$ & NA & $<0.1 \mathrm{c}, \mathrm{m}$ & NA & $<0.06$ & NA & 0.047 b & NA \\
\hline USGS 36 & 433330112565201 & $04 / 21 / 15$ & $<0.026$ & NA & $<0.1$ & NA & $<0.06$ & NA & 0.055 & NA \\
\hline USGS 37 & 433326112564801 & $10 / 05 / 15$ & $<0.026$ & NA & $<0.1 \mathrm{c}, \mathrm{m}$ & NA & $<0.06$ & NA & 0.054 & NA \\
\hline USGS 38 & 433322112564301 & $04 / 21 / 15$ & $<0.026$ & NA & $<0.1$ & NA & $<0.06$ & NA & 0.058 & NA \\
\hline USGS 41 & 433409112561301 & $10 / 08 / 15$ & $<0.026$ & NA & $<0.1 \mathrm{c}, \mathrm{m}$ & $\mathrm{NA}$ & $<0.06$ & NA & 0.036 & NA \\
\hline USGS 42 & 433404112561301 & $04 / 09 / 15$ & $<0.026$ & NA & $<0.1$ & NA & $<0.06$ & NA & 0.043 & NA \\
\hline USGS 43 & 433415112561501 & $10 / 06 / 15$ & $<0.026$ & NA & $<0.1 \mathrm{c}, \mathrm{m}$ & NA & $<0.06$ & NA & $0.013 \mathrm{~b}, \mathrm{t}$ & NA \\
\hline USGS 44 & 433409112562101 & $04 / 08 / 15$ & $<0.026$ & NA & $<0.1$ & NA & $<0.06$ & NA & 0.050 & NA \\
\hline USGS 45 & 433402112561801 & $10 / 07 / 15$ & $<0.026$ & NA & $<0.1 \mathrm{c}, \mathrm{m}$ & NA & $<0.06$ & NA & 0.0657 & NA \\
\hline USGS 46 & 433407112561501 & $04 / 21 / 15$ & $<0.026$ & NA & $<0.1$ & NA & $<0.06$ & NA & $0.022 \mathrm{~b}, \mathrm{n}$ & NA \\
\hline USGS 47 & 433407112560301 & $10 / 08 / 15$ & $<0.026$ & NA & $<0.1 \mathrm{c}, \mathrm{m}$ & NA & $<0.06$ & NA & $0.019 \mathrm{~b}, \mathrm{n}$ & NA \\
\hline USGS 47 & 433407112560301 & $10 / 08 / 15$ & $<0.026$ & 0 & $<0.1 \mathrm{c}, \mathrm{m}$ & 0 & $<0.06$ & 0 & $0.016 \mathrm{~b}, \mathrm{n}$ & 16.4 \\
\hline USGS 48 & 433401112560301 & $04 / 09 / 15$ & $<0.026$ & NA & $<0.1$ & NA & $<0.06$ & NA & $0.030 \mathrm{n}$ & NA \\
\hline
\end{tabular}




\begin{tabular}{|c|c|c|c|c|c|c|c|c|c|c|}
\hline $\begin{array}{c}\text { Station } \\
\text { name }\end{array}$ & Station ID & Date sampled & Benzene & RPD & $\begin{array}{l}\text { Carbon } \\
\text { disulfide }\end{array}$ & RPD & $\begin{array}{c}\text { Carbon } \\
\text { tetrachloride }\end{array}$ & RPD & $\begin{array}{c}1,1,1- \\
\text { Trichloroethane }\end{array}$ & RPD \\
\hline USGS 48 & 433401112560301 & $04 / 09 / 15$ & $<0.026$ & 0 & $<0.1$ & 0 & $<0.06$ & 0 & $0.030 \mathrm{n}$ & 0.2 \\
\hline USGS 51 & 433350112560601 & $04 / 08 / 15$ & $<0.026$ & NA & $<0.1$ & NA & $<0.06$ & NA & 0.076 & NA \\
\hline USGS 51 & 433350112560601 & $04 / 08 / 15$ & $<0.026$ & 0 & $<0.1$ & 0 & $<0.06$ & 0 & 0.072 & 5.8 \\
\hline USGS 52 & 433414112554201 & $10 / 05 / 15$ & $<0.026$ & NA & $<0.1 \mathrm{c}, \mathrm{m}$ & NA & $<0.06$ & NA & $0.017 \mathrm{~b}, \mathrm{n}$ & NA \\
\hline USGS 57 & 433344112562601 & $10 / 07 / 15$ & $<0.026$ & NA & $<0.1 \mathrm{c}, \mathrm{m}$ & NA & $<0.06$ & NA & 0.040 & NA \\
\hline USGS 59 & 433354112554701 & $04 / 08 / 15$ & $<0.026$ & NA & $<0.1$ & NA & $<0.06$ & NA & $<0.030$ & NA \\
\hline USGS 67 & 433344112554101 & $10 / 05 / 15$ & $<0.026$ & NA & $<0.1 \mathrm{c}, \mathrm{m}$ & NA & $<0.06$ & NA & $0.041 \mathrm{~b}$ & NA \\
\hline USGS 77 & 433315112560301 & $10 / 05 / 15$ & $<0.026$ & NA & $<0.1 \mathrm{c}, \mathrm{m}$ & NA & $<0.06$ & NA & 0.065 & NA \\
\hline USGS 82 & 433354112554701 & $04 / 21 / 15$ & $<0.026$ & NA & $<0.1$ & NA & $<0.06$ & NA & $<0.030$ & NA \\
\hline USGS 85 & 433246112571201 & $04 / 08 / 15$ & $<0.026$ & NA & $<0.1$ & NA & $<0.06$ & NA & 0.048 & NA \\
\hline USGS 111 & 433331112560501 & $04 / 07 / 15$ & $<0.026$ & NA & $<0.1$ & NA & $<0.06$ & NA & $0.026 \mathrm{n}$ & NA \\
\hline USGS 112 & 433314112563001 & $10 / 06 / 15$ & $<0.026$ & NA & $<0.1 \mathrm{c}, \mathrm{m}$ & NA & $<0.06$ & NA & 0.049 & NA \\
\hline USGS 113 & 433314112561801 & $04 / 07 / 15$ & $<0.026$ & NA & $<0.1$ & NA & $<0.06$ & NA & 0.042 & NA \\
\hline USGS 114 & 433318112555001 & $10 / 06 / 15$ & $<0.026$ & NA & $<0.1 \mathrm{c}, \mathrm{m}$ & NA & $<0.06$ & NA & 0.093 & NA \\
\hline USGS 115 & 433320112554101 & $10 / 06 / 15$ & $<0.026$ & NA & $<0.1 \mathrm{c}, \mathrm{m}$ & NA & $<0.06$ & NA & 0.031 & NA \\
\hline USGS 116 & 433331112553201 & $04 / 21 / 15$ & $<0.026$ & NA & $<0.1$ & NA & $<0.06$ & NA & 0.037 & NA \\
\hline USGS 123 & 433352112561401 & $10 / 07 / 15$ & $<0.026$ & NA & $<0.1 \mathrm{c}, \mathrm{m}$ & NA & $<0.06$ & NA & $0.019 \mathrm{~b}, \mathrm{n}$ & NA \\
\hline
\end{tabular}


Table 2. Concentrations of selected purgeable organic compounds in groundwater at or near the Idaho Nuclear Technology and Engineering Center, Idaho National Laboratory, Idaho, 2015.-Continued

[Analyses were performed by the U.S. Geological Survey's National Water Quality Laboratory using an analytical method that conforms to U.S. Environmental Protection Agency method 524 (Pritt and Jones, 1989). Concentrations are given in micrograms per liter $(\mu \mathrm{g} / \mathrm{L}) .<0.02$ indicates the concentration was less than the reporting level of $0.02 \mu \mathrm{g} / \mathrm{L}$. Concentrations in bold indicate value exceeds the reporting level. Value Qualifier Codes: b, value extrapolated below the lowest calibration standard; c, see laboratory comments for this result (the reporting level was increased due to interference/the parameter 77041 (carbon disulfide) is a highly variable compound in schedule 4436); $\mathrm{m}$, highly variable compound using this method (flake); questionable precision, and/or accuracy; $\mathrm{n}$, less than the reporting level but equal to or greater than the detection level; $t$, less than the detection level. Replicate, a second sample submitted for analysis using a different identifier. Abbreviations: NA, not applicable. RPD, relative percent difference]

\begin{tabular}{|c|c|c|c|c|c|c|c|c|c|c|c|}
\hline $\begin{array}{l}\text { Station } \\
\text { name }\end{array}$ & Station ID & Date sampled & $\begin{array}{l}\text { Tetrachloro- } \\
\text { ethylene }\end{array}$ & RPD & Toluene & RPD & $\begin{array}{l}\text { Trichloro- } \\
\text { ethene }\end{array}$ & RPD & $\begin{array}{c}\text { 1,1- } \\
\text { Dichloro- } \\
\text { ethane }\end{array}$ & RPD & Remarks \\
\hline CPP 1 & 433433112560201 & $04 / 09 / 15$ & $<0.026$ & NA & $<0.02$ & NA & $<0.022$ & NA & $<0.022$ & NA & \\
\hline CPP 2 & 433432112560801 & $10 / 08 / 15$ & $<0.026$ & NA & $<0.02$ & NA & $<0.022$ & NA & $<0.022$ & NA & \\
\hline USGS 20 & 433253112545901 & $04 / 08 / 15$ & $<0.026$ & NA & $<0.02$ & NA & $<0.022$ & NA & 0.040 & NA & \\
\hline USGS 34 & 433334112565501 & $04 / 21 / 15$ & $<0.026$ & NA & $<0.02$ & NA & $<0.022$ & NA & $0.013 \mathrm{~b}, \mathrm{n}$ & NA & \\
\hline USGS 35 & 433339112565801 & $10 / 05 / 15$ & $<0.026$ & NA & $<0.02$ & NA & $<0.022$ & NA & $<0.022$ & NA & \\
\hline USGS 36 & 433330112565201 & $04 / 21 / 15$ & $<0.026$ & NA & $<0.02$ & NA & $<0.022$ & NA & $0.011 \mathrm{~b}, \mathrm{n}$ & NA & \\
\hline USGS 37 & 433326112564801 & $10 / 05 / 15$ & $<0.026$ & NA & $<0.02$ & NA & $<0.022$ & NA & $0.017 \mathrm{~b}, \mathrm{n}$ & NA & \\
\hline USGS 38 & 433322112564301 & $04 / 21 / 15$ & $<0.026$ & NA & $<0.02$ & NA & $<0.022$ & NA & $0.013 \mathrm{~b}, \mathrm{n}$ & NA & \\
\hline USGS 41 & 433409112561301 & $10 / 08 / 15$ & $<0.026$ & NA & $<0.02$ & NA & $<0.022$ & NA & $0.017 \mathrm{~b}, \mathrm{n}$ & NA & \\
\hline USGS 42 & 433404112561301 & $04 / 09 / 15$ & $<0.026$ & NA & $<0.02$ & NA & $<0.022$ & NA & $0.019 \mathrm{~b}, \mathrm{n}$ & NA & \\
\hline USGS 43 & 433415112561501 & $10 / 06 / 15$ & $<0.026$ & NA & $<0.02$ & NA & $<0.022$ & NA & $<0.022$ & NA & \\
\hline USGS 44 & 433409112562101 & $04 / 08 / 15$ & $0.013 \mathrm{~b}, \mathrm{t}$ & NA & $<0.02$ & NA & $<0.022$ & NA & $0.014 \mathrm{~b}, \mathrm{n}$ & NA & \\
\hline USGS 45 & 433402112561801 & $10 / 07 / 15$ & $<0.026$ & NA & $<0.02$ & NA & $<0.022$ & NA & 0.034 & NA & \\
\hline USGS 46 & 433407112561501 & $04 / 21 / 15$ & $<0.026$ & NA & $<0.02$ & NA & $<0.022$ & NA & $<0.022$ & NA & \\
\hline USGS 47 & 433407112560301 & $10 / 08 / 15$ & $<0.026$ & NA & $<0.02$ & NA & $<0.022$ & NA & $0.015 \mathrm{~b}, \mathrm{n}$ & NA & \\
\hline USGS 47 & 433407112560301 & $10 / 08 / 15$ & $<0.026$ & 0 & $<0.02$ & 0 & $<0.022$ & 0 & $0.016 \mathrm{~b}, \mathrm{n}$ & 6.6 & Replicate \\
\hline USGS 48 & 433401112560301 & $04 / 09 / 15$ & $<0.026$ & NA & $<0.02$ & NA & $0.013 \mathrm{~b}, \mathrm{n}$ & NA & 0.024 b & NA & \\
\hline
\end{tabular}




\begin{tabular}{|c|c|c|c|c|c|c|c|c|c|c|c|}
\hline $\begin{array}{l}\text { Station } \\
\text { name }\end{array}$ & Station ID & Date sampled & $\begin{array}{l}\text { Tetrachloro- } \\
\text { ethylene }\end{array}$ & RPD & Toluene & RPD & $\begin{array}{l}\text { Trichloro- } \\
\text { ethene }\end{array}$ & RPD & $\begin{array}{c}1,1- \\
\text { Dichloro- } \\
\text { ethane }\end{array}$ & RPD & Remarks \\
\hline USGS 48 & 433401112560301 & $04 / 09 / 15$ & $<0.026$ & 0 & $<0.02$ & 0 & $0.013 \mathrm{~b}, \mathrm{n}$ & 2.9 & 0.025 b & 0.8 & Replicate \\
\hline USGS 51 & 433350112560601 & $04 / 08 / 15$ & $<0.026$ & NA & $<0.02$ & NA & 0.076 & NA & 0.097 & NA & \\
\hline USGS 51 & 433350112560601 & $04 / 08 / 15$ & $<0.026$ & 0 & $<0.02$ & 0 & 0.072 & 4.9 & 0.093 & 4.8 & Replicate \\
\hline USGS 52 & 433414112554201 & $10 / 05 / 15$ & $<0.026$ & NA & $<0.02$ & NA & $<0.022$ & NA & $0.021 \mathrm{~b}, \mathrm{n}$ & NA & \\
\hline USGS 57 & 433344112562601 & $10 / 07 / 15$ & $<0.026$ & NA & $<0.02$ & NA & $<0.022$ & NA & $0.011 \mathrm{~b}, \mathrm{n}$ & NA & \\
\hline USGS 59 & 433354112554701 & $04 / 08 / 15$ & $<0.026$ & NA & $<0.02$ & NA & $<0.022$ & NA & $0.013 \mathrm{~b}, \mathrm{n}$ & NA & \\
\hline USGS 67 & 433344112554101 & $10 / 05 / 15$ & $<0.026$ & NA & $<0.02$ & NA & $0.022 \mathrm{~b}, \mathrm{n}$ & NA & 0.061 & NA & $\begin{array}{l}\text { Chloroform: } \\
0.014 \text { b,t }\end{array}$ \\
\hline USGS 77 & 433315112560301 & $10 / 05 / 15$ & $<0.026$ & NA & $<0.02$ & NA & 0.030 & NA & 0.110 & NA & \\
\hline USGS 82 & 433354112554701 & $04 / 21 / 15$ & $<0.026$ & NA & $<0.02$ & NA & $<0.022$ & NA & $<0.022$ & NA & \\
\hline USGS 85 & 433246112571201 & $04 / 08 / 15$ & $<0.026$ & NA & $<0.02$ & NA & $<0.022$ & NA & $0.019 \mathrm{~b}, \mathrm{n}$ & NA & \\
\hline USGS 111 & 433331112560501 & $04 / 07 / 15$ & $<0.026$ & NA & $<0.02$ & NA & $<0.022$ & NA & 0.025 & NA & \\
\hline USGS 112 & 433314112563001 & $10 / 06 / 15$ & $<0.026$ & NA & $<0.02$ & NA & $<0.022$ & NA & $0.019 \mathrm{~b}, \mathrm{n}$ & NA & \\
\hline USGS 113 & 433314112561801 & $04 / 07 / 15$ & $<0.026$ & NA & $<0.02$ & NA & $0.011 \mathrm{~b}, \mathrm{t}$ & NA & 0.027 & NA & \\
\hline USGS 114 & 433318112555001 & $10 / 06 / 15$ & $<0.026$ & NA & $<0.02$ & NA & $<0.022$ & NA & 0.183 & NA & $\begin{array}{l}\text { Chloroform: } \\
0.018 \text { b,n }\end{array}$ \\
\hline USGS 115 & 433320112554101 & $10 / 06 / 15$ & $<0.026$ & NA & $<0.02$ & NA & $<0.022$ & NA & $0.017 \mathrm{~b}, \mathrm{n}$ & NA & \\
\hline USGS 116 & 433331112553201 & $04 / 21 / 15$ & $<0.026$ & NA & $<0.02$ & NA & $<0.022$ & NA & 0.032 & NA & \\
\hline USGS 123 & 433352112561401 & $10 / 07 / 15$ & $<0.026$ & NA & $<0.02$ & NA & $0.014 \mathrm{~b}, \mathrm{n}$ & NA & 0.046 & NA & \\
\hline
\end{tabular}




\section{Summary}

During 2015, the U.S. Geological Survey, in cooperation with the U.S. Department of Energy, sampled groundwater from 31 wells completed in the eastern Snake River Plain aquifer at or near the Idaho Nuclear Technology and Engineering Center (INTEC) at the Idaho National Laboratory for 49 purgeable organic compounds (POCs). Water samples were collected for the purpose of evaluating whether purge water from wells located inside an areal polygon established downgradient of the INTEC must be treated as Resource Conservation and Recovery Act listed waste.

POC concentrations in water samples from two wells were less than their DLDQC; five wells contained one POC concentration greater than the DLDQC; 16 wells contained two different POCs greater than their DLDQC; 7 wells contained three different POCs greater than their DLDQC; and 1 well contained four different POCs greater than their DLDQC. Of the 29 wells with concentrations greater than their DLDQCs, only 20 had concentrations greater than their RLDQC. None of the concentrations exceeded any maximum contaminant levels established for public drinking water supplies.

\section{References Cited}

Ackerman, D.J., 1991, Transmissivity of the Snake River Plain aquifer at the Idaho National Engineering Laboratory, Idaho: U.S. Geological Survey Water-Resources Investigations Report 914058 (DOE/ID-22097), 35 p., accessed December 29, 2015, at http://pubs.er.usgs.gov/publication/wri914058.

Ackerman, D.J., Rattray, G.W., Rousseau, J.P., Davis, L.C., and Orr, B.R., 2006, A conceptual model of ground-water flow in the eastern Snake River Plain aquifer at the Idaho National Laboratory and vicinity with implications for contaminant transport: U.S. Geological Survey Scientific Investigations Report 2006-5122 (DOE/ID-22198), 62 p., accessed December 28, 2015, at http://pubs.er.usgs.gov/publication/sir20065122.

Ackerman, D.J., Rousseau, J.P., Rattray, G.W., and Fisher, J.C., 2010, Steady-state and transient models of groundwater flow and advective transport, eastern Snake River Plain aquifer, Idaho National Laboratory and vicinity, Idaho: U.S. Geological Survey Scientific Investigations Report 2010-5123 (DOE/ID-22209), 220 p., http://pubs.usgs.gov/sir/2010/5123/.

American Society for Testing Materials International, 2010, Standard practice for performing detection and quantitation estimation and data assessment utilizing DQCALC software, based on ASTM practices D6091 and 20 D6512 of Committee D19 on water: ASTM D7510-10, 2 p. (Also available at http://www.astm.org/Standards/D7510.htm.)

Bartholomay, R.C., Orr, B.R., Liszewski, M.J., and Jensen, R.G., 1995, Hydrologic conditions and distribution of selected radiochemical and chemical constituents in water, Snake River Plain aquifer, Idaho National Engineering Laboratory, Idaho, 1989 through 1991: U.S. Geological Survey WaterResources Investigations Report 95-4175 (DOE/ID-22123), 47 p., accessed January 27, 2016, at http://www.osti.gov/scitech/servlets/purl/152647.

Bartholomay, R.C., Tucker, B.J., Ackerman, D.J., and Liszewski, M.J., 1997, Hydrologic conditions and distribution of selected radiochemical and chemical constituents in water, Snake River Plain aquifer, Idaho National Engineering Laboratory, Idaho, 1992 through 1995: U.S. Geological Survey Water-Resources Investigations Report 97-4086 (DOE/ID-22137), 57 p., accessed December 28, 2015, at http://pubs.er.usgs.gov/publication/wri974086. 
Bartholomay, R.C., Tucker, B.J., Davis, L.C., and Green, M.R., 2000, Hydrologic conditions and distribution of selected constituents in water, Snake River Plain aquifer, Idaho National Engineering and Environmental Laboratory, Idaho, 1996 through 1998: U.S. Geological Survey Water-Resources Investigations Report 2000-4192 (DOE/ID-22167), 52 p., accessed January 27, 2016, at http://pubs.er.usgs.gov/publication/wri004192.

Bartholomay, R.C., and Twining, B.V., 2015, Hydrologic influences on water-level changes in the eastern Snake River Plain aquifer at and near the Idaho National Laboratory, Idaho 1949-2014: U.S. Geological Survey Scientific Investigations Report 2015-5085 (DOE/ID-22236), 36 p., http://dx.doi.org/10.3133/sir20155085.

Bartholomay, R.C., Maimer, N.V., and Wehnke, A.J., 2014, Field methods and quality-assurance plan for water-quality activities and water-level measurements: U.S. Geological Survey, Idaho National Laboratory, Idaho: U.S. Geological Survey Open-File Report 2014-1146 (DOE/ID-22230), 66 p., http://dx.doi.org/ofr20141146.

Busenberg, Eurybiades, Plummer, L.N., and Bartholomay, R.C., 2001, Estimated age and source of the young fraction of ground water at the Idaho National Engineering and Environmental Laboratory: U.S. Geological Survey Water-Resources Investigations Report 2001-4265 (DOE/ID-22177), 144 p., accessed December 29, 2015, at http://pubs.er.usgs.gov/publication/wri014265.

Cecil, L.D., Welhan, J.A., Green, J.R., Frape, S.K., and Sudicky, E.R., 2000, Use of chlorine-36 to determine regional-scale aquifer dispersivity, eastern Snake River Plain aquifer, Idaho/USA: Nuclear Instruments and Methods in Physics Research, section B, v. 172, issues 1-4, p. 679-687, accessed December 28, 2015, at https://www.researchgate.net/publication/223443615.

Childress, C.J.O., Forman, W.T., Connor, B.F., and Maloney, T.J., 1999, New reporting procedures based on long-term method detection levels and some considerations for interpretations of waterquality data provided by the U.S. Geological Survey National Water Quality Laboratory: U.S. Geological Survey Open-File Report 99-193, 19 p., accessed November 24, 2015, at http://pubs.er.usgs.gov/publication/ofr99193.

Davis, L.C., 2006, An update of hydrologic conditions and distribution of selected constituents in water, Snake River Plain aquifer, Idaho National Laboratory, Idaho, emphasis 1999-2001: U.S. Geological Survey Scientific Investigations Report 2006-5088 (DOE/ID-22197), 48 p., accessed January 27, 2016, at http://pubs.usgs.gov/sir/2006/5088/.

Davis, L.C., 2008, An update of hydrologic conditions and distribution of selected constituents in water, Snake River Plain aquifer and perched-water zones, Idaho National Laboratory, Idaho, emphasis 2002-05: U.S. Geological Survey Scientific Investigations Report 2008-5089 (DOE/ID-22203), 75 p., http://pubs.usgs.gov/sir/2008/5089/.

Davis, L.C., 2010, An update of hydrologic conditions and distribution of selected constituents in water, Snake River Plain aquifer and perched groundwater zones, Idaho National Laboratory, Idaho, emphasis 2006-08: U.S. Geological Survey Scientific Investigations Report 2010-5197 (DOE/ID22212), 80 p., http://pubs.usgs.gov/sir/2010/5197/.

Davis, L.C., Bartholomay, R.C., Fisher, J.C., and Maimer, N.V., 2015, Water-quality characteristics and trends for selected wells possibly influenced by wastewater disposal at the Idaho National Laboratory, Idaho, 1981-2012: U.S. Geological Survey Scientific Investigations Report 2015-5003 (DOE/ID22233, 106 p., http://dx.doi.org.10.3133/sir20155003.

Davis, L.C., Bartholomay, R.C., and Rattray, G.W., 2013, An update of hydrologic conditions and distribution of selected constituents in water, eastern Snake River Plain aquifer and perched groundwater zones, Idaho National Laboratory, Idaho, emphasis 2009-11: U.S. Geological Survey Scientific Investigations Report: 2013-5214 (DOE/ID 22226), 89 p., http://dx.doi.org/sir20135214. 
Duke, C.L., Roback, R.C., Reimus, P.W., Bowman, R.S., McLing, T.L., Baker, K.E., and Hull, L.C., 2007, Elucidation of flow and transport processes in a variably saturated system of interlayered sediment and fractured rock using tracer tests: Vadose Zone Journal, v. 6, no. 4, p. 855-867, accessed December 31, 2015, at https://www.researchgate.net/publication/250129853.

Fishman, M.J., ed., 1993, Methods of analysis by the U.S. Geological Survey National Water Quality Laboratory-Determination of inorganic and organic constituents in water and fluvial sediments: U.S. Geological Survey Open-File Report 93-125, 217 p., accessed March 25, 2015, at http://pubs.er.usgs.gov/publication/ofr93125.

Garabedian, S.P., 1986, Application of a parameter-estimation technique to modeling the regional aquifer underlying the eastern Snake River Plain, Idaho: U.S. Geological Survey Water-Supply Paper 2278, 60 p., accessed December 28, 2015, at http://pubs.er.usgs.gov/publication/wsp2278.

Goerlitz, D.F., and Brown, Eugene, 1972, Methods for analysis of organic substances in water: U.S. Geological Survey Techniques of Water-Resources Investigation, Book 5, Chap. A3, 40 p., accessed March 25, 2015, at http://pubs.er.usgs.gov/publication/twri05A3_1972.

Greene, M.R., and Tucker, B.J., 1998, Purgeable organic compounds in water at or near the Idaho National Engineering Laboratory, Idaho, 1992-95: U.S. Geological Survey Open-File Report 98-51 (DOE/ID-22146), 21 p., accessed January 4, 2016, at http://pubs.er.usgs.gov/publication/ofr9851.

Leenheer, L.J., and Bagby, J.C., 1982, Organic solutes in ground water at the Idaho National Engineering Laboratory: U.S. Geological Survey Water-Resources Investigation Report 82-15 (DOE/ID-22061), 39 p., accessed March 25, 2015, at http://pubs.er.usgs.gov/publication/wri8215.

Liszewski, M.J., and Mann, L.J., 1992, Purgeable organic compounds in ground water at the Idaho National Engineering Laboratory, Idaho, 1990 and 1991: U.S. Geological Survey Open-File Report 92-174 (DOE/ID-22104), 19 p., accessed March 25, 2015, at http://pubs.er.usgs.gov/publication/ofr92174.

Mann, L.J., 1986, Hydraulic properties of rock units and chemical quality of water for INEL-1—A 10,365-foot deep test hole drilled at the Idaho National Engineering Laboratory, Idaho: U.S. Geological Survey Water-Resources Investigations Report 86-4020 (DOE/ID-22070), 23 p., accessed March 25, 2015, at http://pubs.er.usgs.gov/publication/wri864020.

Mann, L.J., 1990, Purgeable organic compounds in ground water at the Idaho National Engineering Laboratory, Idaho-1988 and 1989: U.S. Geological Survey Open-File Report 90-367 (DOE/ID22089), 17 p., accessed March 25, 2015, at http://pubs.er.usgs.gov/publication/ofr90367.

Mann, L.J., and Beasley, T.M., 1994, Iodine-129 in the Snake River Plain aquifer at and near the Idaho National Engineering Laboratory, Idaho, 1990-1991: U.S. Geological Survey Water-Resources Investigations Report 94-4053 (DOE/ID-22115), 27 p., accessed December 28, 2015, at http://pubs.er.usgs.gov/publication/wri944053.

Mann, L.J., and Knobel, L.L., 1987, Purgeable organic compounds in ground water at the Idaho National Engineering Laboratory, Idaho: U.S. Geological Survey Open-File Report 87-766 (DOE/ID22074), 23 p., accessed March 25, 2015, at http://pubs.er.usgs.gov/publication/ofr87766.

Nimmo, J.R., Perkins, K.S., Rose, P.A., Rousseau, J.P., Orr, B.R., Twining, B.V., and Anderson, S.R., 2002, Kilometer-scale rapid transport of naphthalene sulfonate tracer in the unsaturated zone at the Idaho National Engineering and Environmental Laboratory: Vadose Zone Journal, v. 1, issue 1, p. 89101, accessed December 31, 2015 at http://wwwrcamnl.wr.usgs.gov/uzf/abs_pubs/papers/VZJ.1.89.pdf 
Plummer, L.N., Rupert, M.G., Busenberg, Eurybiades, and Schlosser, P., 2000, Age of irrigation water in ground water from the eastern Snake River Plain aquifer, South-central Idaho: Ground Water, v. 38 , no. 2, p. 264-283, accessed December 29, 2015, at https://www.researchgate.net/publication/227652135.

Pritt, J.W., 1989, Quality assurance of sample containers and preservatives at the U.S. Geological Survey National Water Quality Laboratory, in Pederson, G.L., and Smith, M.M., compilers, U.S. Geological Survey second national symposium on water quality - abstracts of the technical sessions: U.S. Geological Survey Open-File Report 89-409, 150 p., accessed March 25, 2015, at http://pubs.er.usgs.gov/publication/ofr89409.

Pritt, J.W., and Jones, B.E., eds., 1989, 1990 National Water Quality Laboratory services catalog: U.S. Geological Survey Open-File Report 89-386, parts 1-5.

Rattray, G.W., 2012, Evaluation of quality-control data collected by the U.S. Geological Survey for routine water-quality activities at the Idaho National Laboratory, Idaho, 1996-2001: U.S. Geological Survey Scientific Investigations Report 2012-5270, (DOE/ID-22222), 74 p., http://pubs.er.usgs.gov/publication/sir20125270.

Rattray, G.W., 2014, Evaluation of quality-control data collected by the U.S. Geological Survey for routine water-quality activities at the Idaho National Laboratory and vicinity, southeastern Idaho, 2002-08: U.S. Geological Survey Scientific Investigations Report 2014-5027, (DOE/ID-22228), 66 p., http://dx.doi.org/10.3133/sir20145027.

Robertson, J.B., Schoen, Robert, and Barraclough, J.T., 1974, The influence of liquid waste disposal on the geochemistry of water at the National Reactor Testing Station, Idaho, 1952-1970: U.S. Geological Survey Open-File Report 73-238 (IDO-22053), 231 p., accessed December 22, 2015, at http://pubs.er.usgs.gov/publication/ofr73238.

Rose, D.L., and Schroeder, M.P., 1995, Methods of analysis by the U.S. Geological Survey National Water Quality Laboratory-Determination of volatile organic compounds in water by purge and trap capillary gas chromatography/mass spectrometry: U.S. Geological Survey Open-File Report 94-708W, 26 p., http://pubs.usgs.gov/of/1994/0708w/report.pdf.

Taylor, J.K., 1987, Quality assurance of chemical measurements: Chelsea, Michigan, Lewis Publisher, $328 \mathrm{p}$.

Timme, P.J., 1995, National Water Quality Laboratory, 1995 services catalog: U.S. Geological Survey Open-File Report 95-352, 120 p., accessed December 29, 2015, at http://pubs.er.usgs.gov/publication/ofr95352.

U.S. Geological Survey, 1985, National water summary, 1984-Hydrologic events, selected waterquality trends, and ground-water resources: U.S. Geological Survey Water-Supply Paper 2275, 467 p. [Also available at http://pubs.er.usgs.gov/publication/wsp2275.]

U.S. Geological Survey, 2015, Changes to National Water Quality Laboratory (NWQL) procedures used to establish and verify laboratory detection and reporting limits: Office of Water Quality Technical Memorandum 15.02., accessed December 22, 2015, at http://wwwnwql.cr.usgs.gov/rapinotes/15-14_NWQL_TM_15-02_(DQCALC).pdf.

U.S. Geological Survey, [variously dated], The national field manual for the collection of water-quality data: U.S. Geological Survey Techniques and Method, book 9, chaps. A1-A9, [Available at: http://pubs.water.usgs.gov/twri9A/.] 
Wegner, S.J., 1989, Selected quality assurance data for water samples collected by the U.S. Geological Survey, Idaho National Engineering Laboratory Idaho, 1980 to 1988: U.S. Geological Survey WaterResources Investigations Report 89-4168 (DOE/ID-22085), 91 p., accessed December 29, 2015, at http://pubs.er.usgs.gov/publication/wri894168.

Wershaw, R.L., Fishman, M.J., Grabbe, R.R., and Lowe, L.E., eds., 1987, Methods for the determination of organic substances in water and fluvial sediments: U.S. Geological Survey Techniques of Water-Resources Investigation, Book 5, Chap. A3, 80 p., accessed March 25, 2015, at http://pubs.er.usgs.gov/publication/twri05A3.

Williams, L.M., 1996, Evaluation of quality assurance/quality control data collected by the U.S. Geological Survey for water-quality activities at the Idaho National Engineering Laboratory, Idaho, 1989 through 1993: U.S. Geological Survey Water-Resources Investigations Report 96-4148 (DOE/ID-22129), 116 p., accessed February 11, 2016, at http://pubs.er.usgs.gov/publication/wri964148.)

Williams, L.M., 1997, Evaluation of quality assurance/quality control data collected by the U.S. Geological Survey for water-quality activities at the Idaho National Engineering Laboratory, Idaho, 1994 through 1995: U.S. Geological Survey Water-Resources Investigations Report 97-4058 (DOE/ID-22136), 87 p. (Also available at http://pubs.er.usgs.gov/publication/wri974058.) 
Publishing support provided by the U.S. Geological Survey Science Publishing Network, Tacoma Publishing Service Center

For more information concerning the research in this report, contact the Director, Idaho Water Science Center

U.S. Geological Survey

230 Collins Road

Boise, Idaho 83702

http://id.water.usgs.gov 
